\title{
SINGULAR INJURY FROM A CIRCULAR SAW.
}

[Read before the Boston Society for Medical Improvement, March 14th, and communicated for the Boston Medical and Surgical Journal.]

\section{By Samuel C. Cabot, M.D.}

Mr. TinkuM, 41 years of age, twelve years ago froze the surface of both eyes, when riding on a rery cold day in an open sleigh. The sight of one of them was restored perfectly; the other, the left, was left with a central cicatrix on the cornea. Jan. $3 \mathrm{~d}$, while standing about twenty feet from a circular saw, which was cutting a picce of damp lumber, he was struck on the right side of the head by a piece of wood, thrown off by the saw, which measured 22 inches in length, $3 \frac{1}{2}$ inches wide at the butt, and tapered to a point. He was knocked senseless to the floor, and blood flowed from the nose, mouth and outer angle of the right eye in considerable quantity. Dr. John Flint saw him soon after the receipt of the injury, and could discover no wound, except what appeared to be a very trifling one at the outer corner of the right eye, within the commissure of the lids. After he recorered his senses, he had considerable pain in the right side of the head, and was unable to open his mouth. For some time he was in a depressed condition, and suffered screre paroxysms of pain in the right side of the head, which, howerer, gradually diminished in frequency and severity, as his general health and strength improred. A purulent discharge was observed to escape from the corner of the right eye, and that side of his head remained much swollen.

Dr. Flint called me to see him, Feb. 3d. I found a considerable swelling on the right side of his head, extending from the tem. ple back to a point above the ear, where the prominence was quite marked and abrupt, and on pressing upon this prominence I thought I observed a slight yielding, and supposed that a portion of the skull had been fractured, and that it was being detached and in process of elimination. As his health was improring, and there seemed to be no immediate need for surgical interference, I adrised to wait and allow more complete loosening to take place. On the 12 th of February, I saw the patient again, with Dr. Flint, and on making an opening over the most prominent part of the tumor, above the ear, and introducing my finger, I felt what I at first supposed to be a piece of loose bone, but on pulling it out, which I did with some difficulty with a pair of long-jawed tooth forceps, I found it to be a piece of wood, and on following up with longer forceps, I continued to extract pieces from under the temporal muscle, and down under the zygomatic arch, until they amounted to what $I$ here show. The largest piece measures 2 inches in circumference, 18 inches in length, and 8 of an inch in its largest transverse diameter. I found that there was a hole through the outer wall of the orbit, at about the junction of the upper part of the orbital process of the malar bone and the lower part of

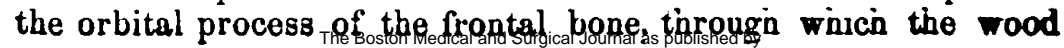


must have passed, and then impinging on the under side of the zygoma, it eplit in pieces, part going straight back behind and beyond the temporal muscle, and part turning down, and remainiug bchind the zygoma.

I think no one who had seen this man, would have imagined that it could be possible for such a large piece of wood to hare got through what appeared so insignificant an opening as the external wound presented, and more especially, without crushing the eyeball in its passage. I should have sooner mentioned, that though the eye showed some inflammation of the iris to have occurred, as shown by an irregular pupil, and also some commencement of opacity of the lens, or of its capsule, still it was much less than one could hare supposed possible from such an injury. Mr. T. could see somewhat with the injured eye, at the time of my operation upon him. The external shape and appcarance of the ball did not show any mark of injury, except the apparently trifling opening between the ball and outer angle, through the conjunctiva. It seems strange that the wood did not pass down into, and through the orbit, and thence into the brain, instead of forcing its way through a strong bone, at an angle to its surface so acutc as this seems to have been. It must be accounted for by the great relocity at which it was propelled. Mr. T. has entirely recovered from the effects of his injury, so far as pain and geineral symptoms are conccrned. but his eje, I fear, will never be of any use to him; and there is still a slight discharge from the wound.

\section{Zipporta of Jevital Societiey.}

\section{EXTRACTS FROM THE RECORDS OF THE BOSTON SOCIETY FOR MEDICAL IMPROVEMENT. BY FRANCIS MINOT, M.D., BECRETARY.}

Frb. 25th.-Diphtheria. Dr. H. J. Bigelow remarked that at a previous meeting of the Society he had commented upon the variety of lesion and tendency which had characterized the various epidemics of diphtheria us recorded by various writers. Amung these are endemia, futal and seemingly poisonous depression of the system, contagion, false meinbrane in the throat and elsewhere, and even rash. When an epidemic of this general type was known to prevail, he considered it fair to refer lighter cases of sore throat, \&c., to the same prevailing influences, and for cunverience to use a common name to group them, although the type might vary a little. On the other hand, if a precisely similar, but sporadic, case occurred when no epidemic prevailed, he should not so group it. As an instance in point, Dr. B. cited the case of a lady in Worcester, who, about eight years ago, died, immediately after nursing her clild, from strangulation by a fap of false membrane in the larynx, as in the case of Di: Adams, slie having been out four days previously. This case he at the time considered to be one of adult croup. Dr. B. referred to his rernarks before this Society about a year ago suggestiag that the type of cruap, now nut 